\title{
Specification of System Object of State Regulation in the Information Russian Society
}

\author{
Kirshin I. A. ${ }^{1} \&$ Pachkova O. V. ${ }^{1}$ \\ ${ }^{1}$ Institute of Management, Economics and Finance, Kazan Federal University, Kazan, Russia \\ Correspondence: Kirshin I. A., Institute of Management, Economics and Finance, Kazan Federal University, \\ Kazan, 420008, Russia.
}

Received: December 27, 2014

Accepted: February 19, 2015 Online Published: April 30, 2015

doi:10.5539/ass.v11n11p34

URL: http://dx.doi.org/10.5539/ass.v11n11p34

\begin{abstract}
The article determined the main problems of designing a system object of state regulation in the information of the Russian society, tentatively called "Concept 7I". Considered phased design of the proposed concept consists of the following elements: "Information", "Intelligence", "Innovation", "Institute", "Infrastructure", "Investments", and "Indicators". Each element of the system identifies the main features installed structural forward and backward linkages, separated objects of state regulation and administration.
\end{abstract}

Keywords: information, intelligence, innovation, institutions, infrastructure, investment, indicators, the system object of state regulation, information economy, information society, the principle of feedback, the method of "black box" information and communication sector

\section{Introduction}

Effective solution to the problems of improving the process of reproduction of information as a key provision of the information type of economic growth is one of the major challenges of our time. Lack of information system approach to the specification of the object of state regulation in the development of a government policy of information society in the Russian Federation are responsible for the relevance of application of systems analysis in the study of the information economy and information society. From the standpoint of government regulation is necessary to the continuous improvement of the methodology of information economy. Need a methodology linking economic growth with modern information society fixing her understanding of how the condition and result of economic growth.

For the development of the state strategy of building the information society, based on the expanded reproduction of information resources by the authors justified the selection as an object of state regulation system of the complex, which includes the following elements: "Information", "Intelligence", "Innovation", "institute", "Infrastructure", "Investments "," Indicators "defined by us as "Concept 7I".

Since lack of information system approach to understanding the control object and the formation of a government policy development of the Information Society in Russia require the consideration of this issue. That information system approach should provide an impetus for advancing growth of the information economy and the further development of the information society under the influence of reproduction of information resources.

\section{Main}

Considering the system as a set of interrelated elements that have properties different from the properties of the elements forming this set, will be considered as a kind of object of management integrity.

Exploring the whole, one can understand the specifics of its components. A necessary and sufficient condition for the functioning of the system as a whole is mandatory existence of links between elements, where the connection - is the transfer of material, energy and most importantly (in this study) component information from one object to another. In the socio-economic (business) communication systems or economic relations can be organized in a planned manner, which is the state or develop spontaneously on the basis of market laws. In these systems, a special role is played by the pragmatic nature of the information, when it is used to achieve the goals.

The bases of our proposed Concept $7 I$ are works of domestic and foreign scholars, gradually mapping out the control object as a kind of integrity. 
The nature of information is twofold. On the one hand, the information can not in principle exist and function without the cost of real-energy carrier and thus today the information - it's only natural laws, functional global, priority strategic resource efficient growth of socio-economic activities and development of mankind. On the other hand, information is the intellectual base and performs a series of creative activity of certain functions. Creating and augmenting information is not an end in itself, and the power base of any intellectual process. The intellectual basis of objective and logical ensures the effectiveness of purposeful creativity. It is a global driving force, as well as an effective lever of social and economic activities and development are inextricably linked with the phenomenon of information and the information of the individual and the problems of social labor.

Intellectual life - unity real-energy and perfect-information in the process of thinking and expression of the will, i.e., this single psycho - information process. This procedural unity forms a transition to the content, namely, the objective reality of a phenomenon or process goes into specific (abstract) form, which in this state is called information. In the process of purposeful thinking already idealized phenomenon - information - is acting as their content.

Innovation framework should also be considered in an integrated system of information and intellectual resources. All forms of human activity, and especially intellectual creativity, mediated by information and have therefore to be technology.

In praxeological terms (from the Greek. praktis - practice - theory of efficient organization of activities), scientific discoveries creatively transformed into scientific and applied technological solutions (inventions), in engineering studies, and the last - in production technologies and products in some way. Technological equipment when it is considered the most advanced in full compliance with the principles of resource conservation and minimizing the cost of raw materials and energy. Socio-humanitarian direction of accelerating technological processes - a guarantee of timely meets the vital needs of the people. Thus, the intellect in its fundamental essence doomed to innovative improvement of socio-economic technologies in all sectors without exception.

In the context of the proposed system-information methodology fundamental science, should be seen as a major producer of the most objective and reliable information resource of modern economic growth. But in terms of its social system-wide information resource function and science itself is performed only when the transition (transformation) of knowledge in economic space, where they become factors of production or productive force.

Consider innovative component, using the definition given by J. A. Schumpeter (Schumpeter, 2007, c.132), which states that produce - then combine existing in our field and force things. Produce something else anyway then create other combinations of these things and forces.

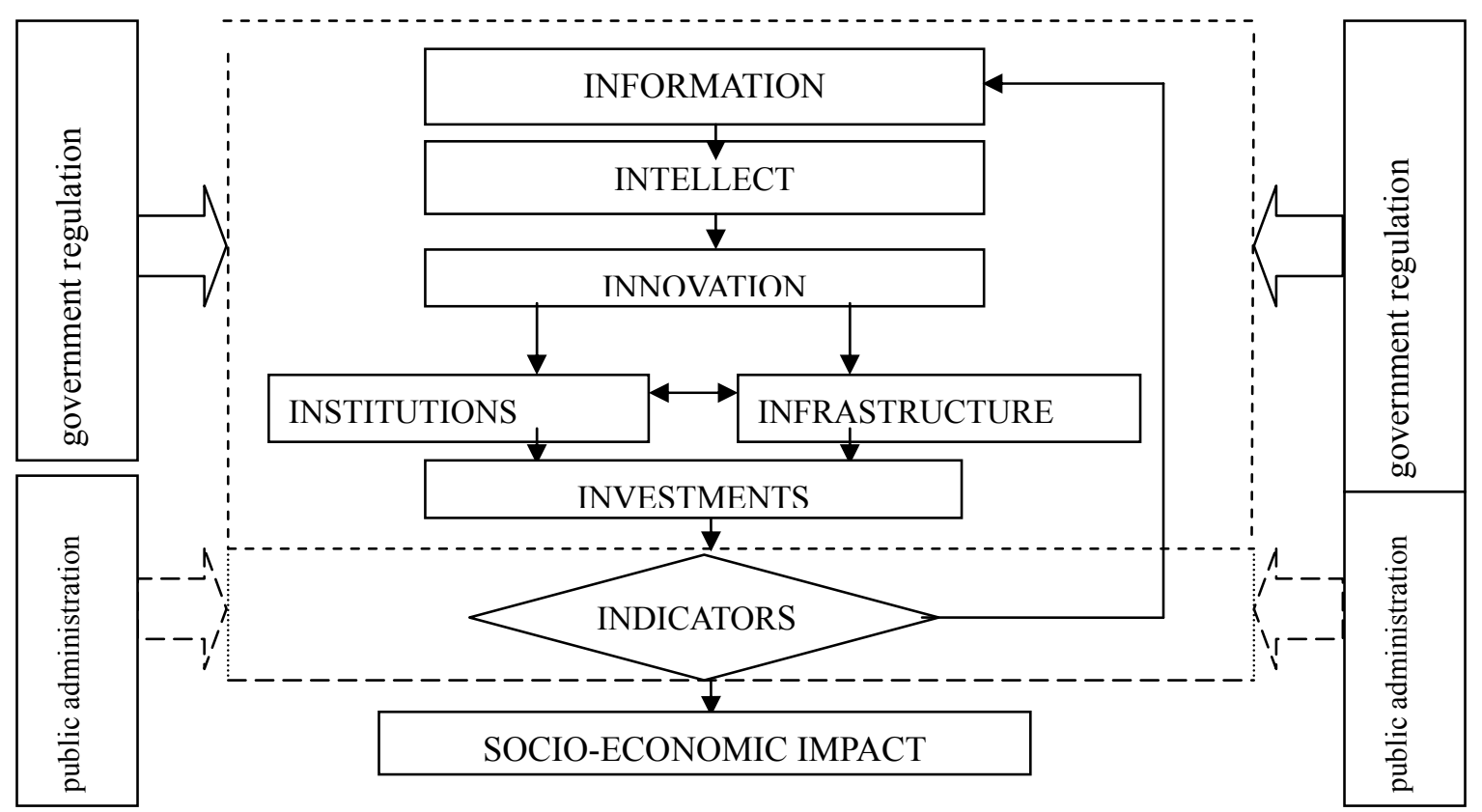

Figure 1. Block diagram of the system object of state regulation "Concept 7I" 
Author's approach is a generalization of the above and is offered as part of this research subject to state regulation in the complex system information society count "Concept 7I" consisting of "Information", "Intelligence", "Innovation", "Institute", "Infrastructure", "Investments" "Indicators" (Figure 1).

Therefore, to develop a state strategy of building the information society and the involvement of information resources in the process of reproduction is necessary, using the system analysis, as an object of state regulation to use complex "Concept 7I".

Each of the elements of the "Concept 7I" performs the following basic functions:

1. Information - the basis for the intellectual (artistic, creative) economic activities.

2. Intelligence - carrier and creator of the new information.

3. Information and intelligence together perform a selective function for the selection of innovation.

4. Institutions - form a legal framework and traditions.

5. Infrastructure performs and provides a linking function.

6. Investments - the function of financial security of the whole system, "7I".

7. Indicators give an estimate and indicate the vector of further development of the "7I".

Structural analysis of the modern economy and the recognition of the leading role of R\&D in the field of sustainable economic growth, suggests that IE is not only a set of independent entities, whose activities are linked and regulated market and other mechanisms, but also as an information space, which has specific tendencies of his development.

Binding element of the information space are the objects of the information infrastructure, providing the general conditions of informational interaction of society.

We pay attention to the integration role of the infrastructure complex in the system of industrial relations: "Infrastructure operations to restore the unity and continuity of the discrete manufacturing operations by providing the material conditions for each subsequent stage, supplying the means and objects of labor, energy, and information in the right place, at the right time and in the right quantity".

The importance of the role of the infrastructure of the complex is enhanced in terms of progressive scale of the social division of labor, economic isolation and autonomy of economic systems.

K. Marx noted the following signs of capital in industries that now usually referred to infrastructure: "The simultaneous service of several capitals as general conditions for their production and circulation; participation as a productive and unproductive consumption; use is not in a particular production process, as well as communicating artery for a variety of processes for production of special capital "(Marx \& Engels, c.215).

On the basis of the further deepening of the social division of labor under the influence of reproduction of information resources is separated from the main production infrastructure functions. Thus, the operation of the information infrastructure as an integral part of the overall infrastructure to ensure the "reality" of the information flows between the owners and users of information. Parameters defining the intensity of the operation of the information infrastructure depends on the technical equipment, weights and information flows circulating in the economy.

For successful economic activities requires a quality rules, namely institutions and their core - the regulatory framework, which should be clear and transparent for all economic actors. Proceeding from this, in the context of the proposed "Concept 7" assumes the development of the normative-legal base in all seven directions in accordance with a system-information approach.

The spread of ICT is highly renewability and versatility, led the transformation of information into a strategic resource for the transformation of traditional factors of production. The immediate result of the accumulation, use and transfer of information, integrating into the factors of production and, above all, with difficulty is the creation of innovative technologies, the use of which in economic activity can be generated by the effect of increasing returns.

As stated above "Investments" perform the function of financial support ongoing innovation that has been selected for "information" and "intelligence". As the table shows the contribution of ICT sector to total value added in 2010, occupies a prominent place in the business sector, as in the first seven countries it exceeds $10 \%$. 
Table 1. The contribution of the sector ICT (ICT) to the total value added and total employment in the business sector, $2010 \mathrm{y}$. or latest available year

\begin{tabular}{ccccc}
\hline № & Countries & $\begin{array}{c}\text { The value added of the } \\
\text { ICT sector to the total } \\
\text { cost of the business sector } \\
\text { (in\%) }\end{array}$ & $\begin{array}{c}\text { Employment in the ICT } \\
\text { sector to the total } \\
\text { number of employes } \\
\text { in the business sector } \\
\text { (in\%) }\end{array}$ & $\begin{array}{c}\text { The ratio of value added } \\
\text { to employment ICT sector } \\
\text { ICT / rating }\end{array}$ \\
\hline 1 & Israel & 14,7 & 8,5 & 1,73 \\
2 & Finland & 13,9 & 9,3 & 1,49 \\
3 & IrelandИpландия & 13,0 & 7,5 & 1,73 \\
4 & South Korea & 12,2 & 6,1 & $2,00 / 5$ \\
5 & Malaysia & 12,1 & 7,1 & 1,70 \\
6 & Uruguay & 10,5 & 2,9 & $3,62 / 1$ \\
7 & Sweden & 10,4 & 8,4 & 1,24 \\
8 & Hungary & 9,9 & 7,7 & 1,29 \\
9 & United Kingdom & 9,6 & 6,1 & 1,57 \\
10 & Czech Republic & 9,0 & 5,8 & 1,55 \\
11 & USA & 9,0 & 4,0 & $2,25 / 4$ \\
$\ldots$ & $\ldots$ & $\ldots$ & $\ldots$ & $\ldots$ \\
26 & Mexico & 5,0 & 2,2 & $2,27 / 3$ \\
27 & Brazil & 5,0 & 2,1 & $2,38 / 2$ \\
28 & Russia & 4,9 & 4,6 & $1,07 / 31$ \\
29 & Hong Kong & 4,7 & 3,1 & 1,52 \\
30 & Cuba & 4,1 & 2,7 & 1,52 \\
31 & Croatia & 3,0 & 1,9 & 1,58 \\
\hline
\end{tabular}

Source: compiled and calculated by the authors based on (UNCTAD).

If we consider the ratio of value added ICT-sector employment in the ICT sector as a measure of efficiency, the maximum rate is Uruguay and Russia recently. A five countries leader is: Uruguay, Mexico, Brazil, United States, The Republic of Korea.

The development of national production in ICT unthinkable without the participation of foreign capital and technology. The main source of foreign direct investment in the ICT sector are multinational corporations. In many countries, the share of national production of the ICT sector accounted for multinational corporations, it is overwhelming. Thus, more than $90 \%$ of the production of computers in the Czech Republic and Ireland carried units of foreign companies. The comparable figure for Germany, Hungary, France, Finland and the UK - from 45 to $70 \%$ (Brodsky, 2013).

Output growth of ICT and compete successfully in foreign markets, is impossible without a targeted investment in R\&D. So investment in OECD (Organisation for Economic Cooperation and Development) is \$ 130 billion. Per year, $40 \%$ of them in the United States. In this area in OECD countries occupied 1 million. People. Up to $25 \%$ of all R\&D in ICT is interdisciplinary in nature and funded by the automotive industry, defense industry, the financial sector. In the area of patenting lead the US, but China's share has tripled in a decade. R\&D spending by the ICT sector is the largest in the OECD. For comparison, in the automotive industry spent 2.5 times less on R\&D. On average in OECD ICT companies have financed $25 \%$ of all R\&D industry, with the figure for the United States, Canada, Japan, and Ireland - more than 30\%. In Finland and the Republic of Korea - $60 \%$ (Brodsky, 2013).

Globally, the main investors are the major R\&D company ICT and related sectors. Russia still Soviet-era practice of applied R\&D funding by the State, including on the basis of grants is ineffective. In the private sector customer patent developments have not yet been formed and received no institutional design. In this role could speak of the IT sector - services (systems integrators) in the case of these companies achieve sufficient size and access to foreign markets of ICT.

In world practice, a number of systems used indices to measure progress towards the development of the information society and information economy. The result of the calculations is the resulting composite index, which is calculated on the basis of quantitative and qualitative indicators derived from data from different sources: the statistics of international organizations; official statistics bureau countries studied; Calculations 
made by a group of analysts' research organizations, and others. At the present time, information and knowledge are the main drivers of global economic growth, as well as key factors of competitiveness in international markets.

\section{Conclusions}

In the domestic economy, the problem of the specification of the system of state regulation of the object is determined by the objective properties of Russian development institutes. These include: economic significance of administrative resources, a greater degree of socio-economic stratification of society, low social mobility. It defines a large degree of opportunism and manifestations of deviant behavior (violating the established norms) domestic businesses.

Target setting of progressive social and political forces of the Russian Society for the construction of the information economy determines the need for the transformation of property relations and, above all, the resolution of conflicts of formation of the Institute of Intellectual Property. It is well known that the institutionalization of intellectual property increases the transaction costs of diffusion of knowledge. Intellectual property rights, normalizing free movement of products of intellectual activity, create restrictions of information economy. Intellectual property, to some extent, impedes the free circulation of knowledge and the development of creative activity. Restriction of free movement of knowledge and information leads to a loss of knowledge of the status of the general productive resource.

In the course of the study consistently addressed all seven categories included in the system object of state regulation "Concept 7 and" that confirms the process of unification of these categories as a result of the evolutionary development of the modern economic system. The positive effect of "7I" in the system and the regulation of information - a matching airbag, appearance synergies. We believe that this system solves this problem because it has the ability to change its state and structure in response to the possible perturbations, since the variety of perturbations requires corresponding diversity of possible states.

\section{References}

Brodsky, N. (2013). World trends in ICT and the experience of Russia. Retrieved March 9, 2013, from http://www.connect.ru/article.asp?id=9502

Kirshin, I. A. (2014). Ecological restrictions of modern economic growth. Studies on Russian Economic Development, 25(3), 276-282. http://dx.doi.org/10.1134/S1075700714030046

Kirshin, I. A., \& Kuzminov, S. V. (2014). Evaluation method development for regional economies competitiveness. Mediterranean Journal of Social Sciences, 5(18), 159-164.

Marx, K., \& Engels, F. Soch. (2nd ed., T.46, ch. 1, 440c).

Schumpeter, J. A. (2007). The theory of economic development. Capitalism, Socialism and Democracy. Penguin Books. (Anthology of economic thought).

The United Nations Conference on Trade and Development (UNCTAD). Retrieved March 9, 2013, from http://unctadstat.unctad.org/TableViewer/tableView.aspx

\section{Copyrights}

Copyright for this article is retained by the author(s), with first publication rights granted to the journal.

This is an open-access article distributed under the terms and conditions of the Creative Commons Attribution license (http://creativecommons.org/licenses/by/3.0/). 